\title{
An Estimation Method of Running Down Distance of Slope Failure Debris by a Fuzzy Inference Method Based on $L^{-} \mathbf{R}$ Type Membership Function
}

\author{
Hiroyuki Yoshimatsu* and Saburo NAKAMURA**
}

\begin{abstract}
概 要
斜面土砂災害において最も人的な被害の大きい現象はがけ崩れであり, 移動地塊の速度が急速なことが主要な原 因である。これら災害の防止のため崩土の流下距離の予測手法の確立が強く叫ばれている。崩土の流下距離の予測に 関する研究は, 災害実態の統計解析より相関関係をもとに予測式を検討する手法が議論されている。しかしながら従 来の統計解析手法は, 斜面形態などの質的及び量的記述の要因などに関してファジィネスを有しているにも関わら ずその特性を考慮した解析がなされておらず, 崩土の到達距離の予測手法の精度について検討が困難であった。

当論文は,これまでの手法によらず災害データはファジィネスを有する特性があることから,崩土の流下距離に関 与する要因を L-R 型のメンバーシップ関数で表し, ニューラルネットワークで用いられているデルタルールを用い て学習し，この学習結果のファジィ推論より崩土の流下距離の予測を行う手法を検討した結果，以下の結論を得た。

1 ) L-R 型のメンバーシップ関数を用いることによって，ファジィ事象確率に従ってメンバーシップ関数を決定 できる

2 ) L-R 型のメンバーシップ関数による簡略化推論手法の学習手法を定式化し, 従来手法に比較して演算が簡単 である

3 ) 提案する手法を用いて崩土の流下距離の予測を実施したところ, 数量化理論 1 類より精度の高い手法であり, 学習機能を有することにより汎化性の高い手法である。

4 ) 学習後のメンバーシップ関数分布形状を検討することによって, 解析に用いる要因の曖昧性が検討でき, 要因 の適切な再区分設定が可能である。

キーワード: 崖崩れ, 崩土の到達距離, ニューラルネット, ファジィ推論
\end{abstract}

\section{Introduction}

Slope failure is perhaps the most damaging type of landslides' disaster on civilization, mainly due to the rapid speed of moving soil mass. Methods of estimating the distance slope failure debris that runs down a slope are thus essential for disaster prevention. Previous research on estimating slope failure debris has focused mainly on two methods:

1) Devising an estimation formula based on correlation derived from statistical analysis of disasters (Okubo et al., 1995).

2) Solving a momentum conservation principle by numerical analysis based on the factors which affect the movement of slope failure debris (Ashida et al., 1983).

The statistical analysis method enables both qualitative and quantitative records to be used

* Civil Engineering Dept., Ehime Prefecture

** National Defense Academy such as slope shape, and can reveal the extent to which elements affect the distance of slope failure debris runs down a slope. However, analysis is only possible based on existing data and is thus not so practical since the required data are a great much number and the data must be reanalyzed whenever new data is added. In contrast, the method which analyzes a kinetic model through numerical calculation enables the effects of the kinetic speed of slope failure debris to be predicted and can provide valuable data for taking preventive measures such as evaluating the impact force. However, the analysis parameters greatly influence accuracy, and it is difficult to adjust these parameters.

Instead of relying on these conventional methods, we used the fact that disaster data possess fuzzy characteristics; We represented factors affecting the run-down distance using $\mathrm{L}-\mathrm{R}$ type membership functions and trained these func- 
tions with the delta rule used in a neural network. This paper presents a highly practical method using a fuzzy inference system based on these learning procedures to estimate the run-down distance of slope failure debris.

\section{Fuzzy Inference Method and Neural Network}

The fuzzy inference method is based on deducing a single independent fuzzy proposition from a variety of fuzzy propositions. The authors previously considered the possibility of adopting this method for estimation priorities such as judging slip surfaces and evaluating the fluctuation of groundwater in landslide areas (Yoshimatsu et al., 1995a, 1995b). This procedure, called the simplified inference method, expresses the rule antecedent in actual numeric values and is characterized by a simple inference structure, fast computer calculation time, and inference results that are almost equal to those obtained by the direct inference method (Tanaka, 1991). It successively adopts units that correspond to the inference rules that are necessary in the course of learning, and the self-tuning of membership functions are conducted using the delta rule (Nomura et al., 1992, Masuda et al., 1993).

Nevertheless, the membership functions obtained after self-tunings in conventional methods are merely fine adjustments of the initial tuning. Furthermore, even if a rule that is close to the technician's expectations is set up, the initial membership function must be tuned with equally high accuracy. Moreover, since there are no rules between the membership functions that observe the fuzzy probability event during self-tuning, the result would be irrational, as shown in Fig. 1. In other words, even if the value of a membership function of a certain element is 1 for example, an adjacent membership function would still have an

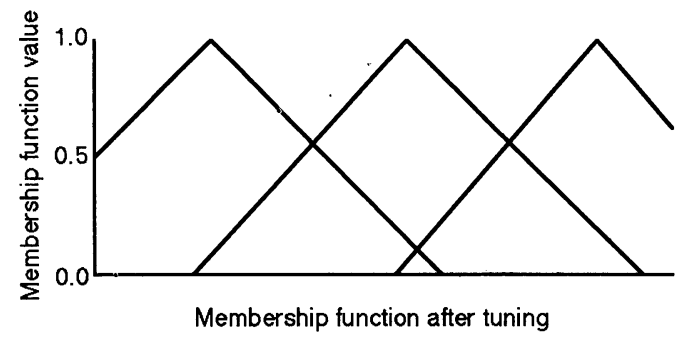

Fig. 1 Membership function after tuning individual value. Although the concepts of the membership functions in each problem are generally understood by experience, they are rarely known specifically beforehand and they rarely form non-symmetrical triangular distributions. Therefore, there is still room for improvement on these issues when applying this method for engineering purposes.

Instead of the current subjective method, this paper investigates a new mean of objectively tuning membership functions based on category score values obtained from the quantification theory I applied to disaster data. It then proposes a method for conducting fuzzy inference with the derived L-R type membership functions.

\section{Fuzzy Inference Method Based on $L-R$ Type Membership Functions}

In order to conduct fuzzy inference, it is necessary to appropriately tune the membership functions. Until now, methods of identifying membership functions have been based on subjective judgments such as the simple average value method, the transient average value method and the boundary point estimate method (Japan Society for Fuzzy Theory and Systems. 1992) as well as those based on fuzzy probability (Tamaki et al., 1993).

Here, instead of relying on the subjective judgment of the observer, membership functions are objectively set with category score values acquired by the quantification theory I in order to analyze the quantitative and qualitative data as this combination calculation. The procedure is as follows:

1) The probability density function is sought with the maximum likelihood in cases involving quantitative elements such as rainfall amount.

2) This probability density function is then categorized so that the occurrence probabilities of the phenomena are equal.

3) The difference between the categorized adjacent average values is given by the following equation and the level of significance is based on this difference.

$$
x_{(k)}=\frac{\sum_{j-1}^{n(k)} y_{j}}{n_{(k)}} \quad(k=1,2, \cdots \cdots l)
$$

Where, $y_{j}$ is the external criterion, $n_{(k)}$ is the number in each category and $x_{(k)}$ is the average 
value of each category.

4) The categorization is judged successful if the difference is significant, and categorization is repeated if judged unsuccessful.

The above procedure is necessary only for quantitative data since qualitative data is already categorized.

5) Using the categorized qualitative and quantitative elements, the category score is determined using the quantification theory I.

Since fuzziness exists in disaster data used for the analysis, it should also exist in the category segment value and the category score value resulting from the above procedure. Therefore, the following conditions can be assumed:

- A certain phenomenon cannot possess 3 segmented phenomena simultaneously.

- A conditional probability determined by a segmented phenomenon exists in a certain phenomenon.

Thus, when the conditional probability is determined by arranging the category score values in order of their influence on the external criterion in accordance to the analytical characteristics of the quantification theory I, an L-R type membership function can be produced when the membership function uses 1 as the corresponding category score value, the other score value is 0 , and the area between these two values' changes linearly. Calculations based on the multi-dimensional quantification theory usually use quantitative data, and since the characteristics of the membership functions of each category segment are directly applied to the fuzzy inference calculation, the category segment values are used as is for membership function tuning. In other words, the membership function uses a central value of the category segment of 1 , while the other category segments use 0 , as with qualitative data.

The slope failure disasters' data used in this analysis is based on 330 cases selected from approximately 2000 cases which occurred in Japan from 1983 to 1985 and were caused by heavy rainfall. The 330 cases were chosen by extracting the longest and shortest slope failure debris run-down distance from each page of the "Report of Slope Failure Disasters" compiled by Mitsui et al. (1987), and then designating 3 positions which equally divide each run-down distance. This procedure covered the entire report.

The solid lines in Fig. 2.1 to 2.5 show the configuration of the membership functions acquired by applying the method presented in this paper to the previous data. Table 1 shows the elements used in this analysis which were judged to significantly affect the run-down distance (Okubo et al., 1995).

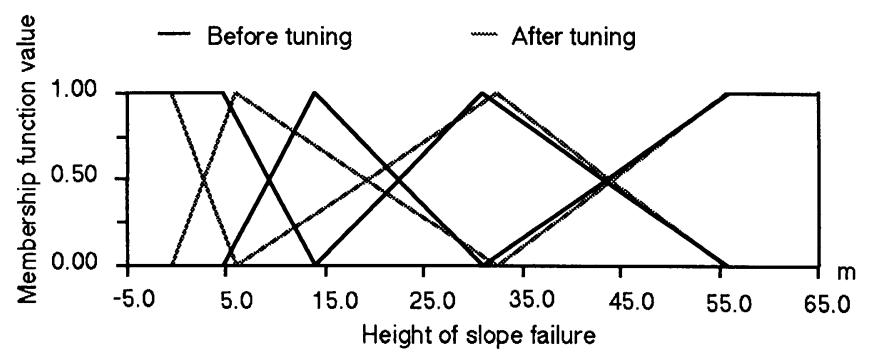

Fig. 2.1 Membership function for height of slope failure

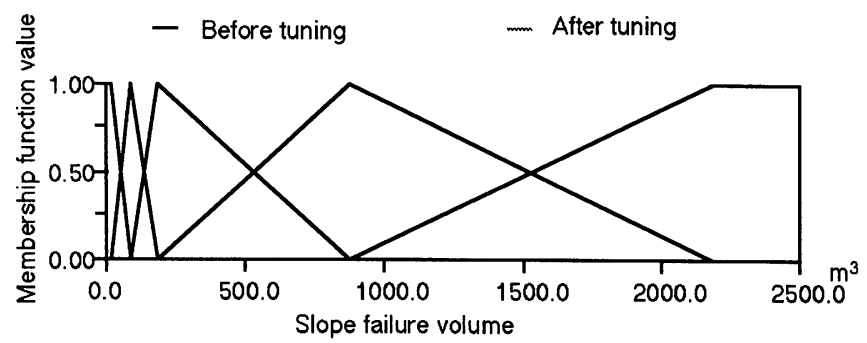

Fig. 2.2 Membership function for slope failure volume 


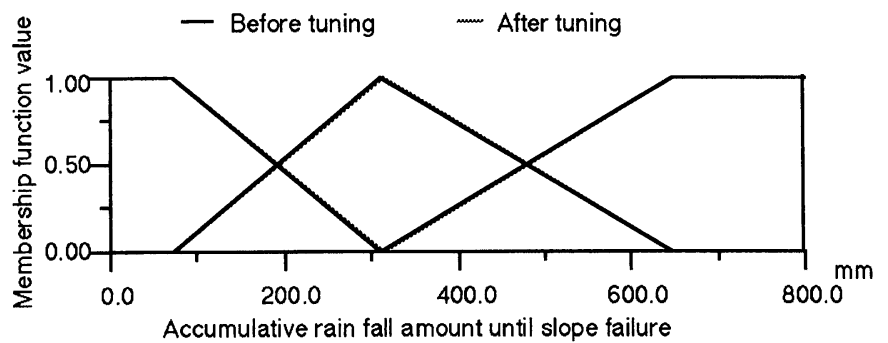

Fig. 2.3 Membership function for accumulative rain fall amount

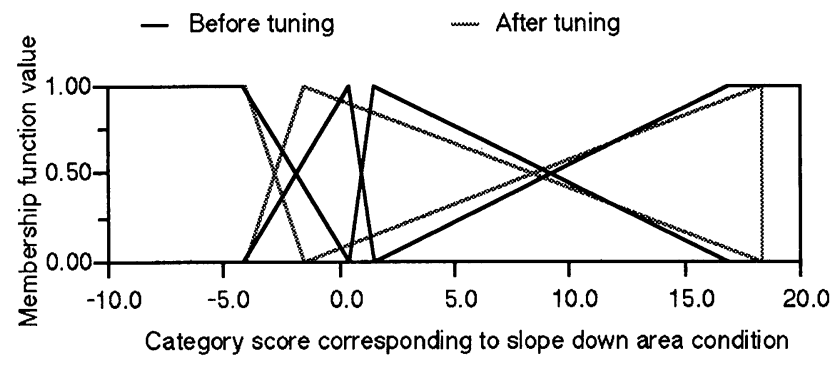

Fig. 2.4 Membership function for slope down area condition

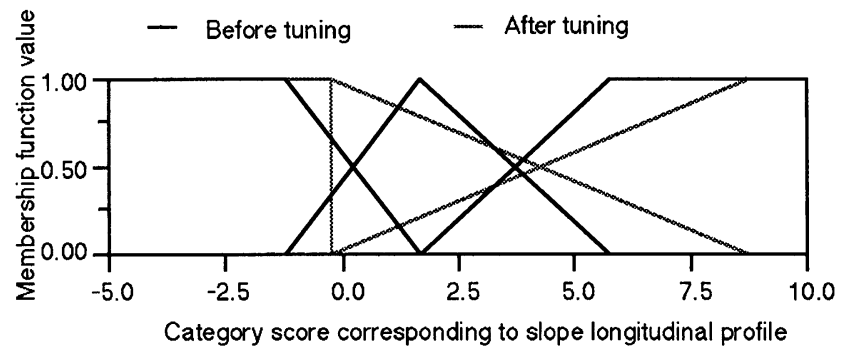

Fig. 2.5 Membership function for type of slope longitudinal profile

Furthermore, to reduce the calculation time and volume, qualitative data concerning the down area and the longitudinal section of the slope was categorized according to the conditions shown in Table 1 using the category score values from the analysis results of quantification theory I.

When the L-R type membership function is represented by the symbol in Fig. 3, the inference structure is simplified by the following equation where the membership functions as $A_{h i}$ are the input variables, $x_{i}$ is the rule antecedent and the rule consequent of output variable $y_{i}$ and is represented by a real numeric value $w_{h j}$.

Rule: $h$

If $x_{1}$ is $A_{h i}\left(x_{j}\right)$ and $\cdots \cdots$ and $x_{m}$ is $A_{h m}\left(x_{m}\right)$ then $y_{1}$ is $w_{h 1}$ and $\cdots \cdots$... and $y_{n}$ is $w_{h n} \cdots(2)$

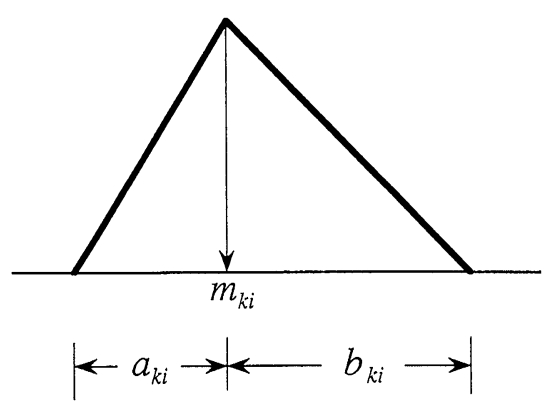

Fig. 3 Definition of membership function

Here, self-tuning through learning of rule antecedent membership function $A_{h i}$ is done within the limits of fuzzy probability. Each membership function $A_{h i}$ can thus be expressed by the following equations. 
$k=1$

$$
\begin{gathered}
A_{k i}\left(x_{1}\right)=\left\{\begin{array}{cc}
1 & x_{k i} \leq m_{k 1} \\
1-\left|\frac{m_{k i}-x_{k i}}{a_{k i}}\right| & x_{k i}>m_{k 1} \cdots(3)
\end{array}\right. \\
k=2 \cdots \cdots t-1 \\
A_{k i}\left(x_{i}\right)=\left\{\begin{array}{cc}
1-\left|\frac{m_{k i}-x_{k i}}{a_{k i}}\right| & x_{k i} \leq m_{k i} \\
1-\left|\frac{x_{k i}-m_{k i}}{b_{k i}}\right| & x_{k i}>m_{k i}
\end{array} \cdots(4)\right. \\
k=1 \\
A_{k i}\left(x_{i}\right)=\left\{\begin{array}{cc}
1-\left|\frac{x_{k i}-m_{k i}}{b_{k i}}\right| & x_{k i} \leq m_{k 1} \cdots(5) \\
1 & x_{k 1} \leq m_{k 1}
\end{array}\right.
\end{gathered}
$$

Where, $a_{k i}$ and $b_{k i}$ are given by the following equation based on the prior rule of fuzzy probability:

$$
\begin{aligned}
& a_{k i}, b_{k(i+1)}=m_{k 1}-m_{k(i+1)} \\
& a_{k(i+1)}, b_{k i}=m_{k(i+1)}-m_{k i}
\end{aligned}
$$

Therefore, $\mu_{h}$, which is the conformity level of the rule antecedent of each inference rule, is given by the following equation as an algebraic product:

$$
\mu_{h}=A_{h 1}\left(x_{1}\right) \cdots \cdots \cdot A_{h m}\left(x_{m}\right)
$$

Furthermore, $y_{j}$, which is the inference result of the simplified fuzzy inference method, is thus given by the following equation:

$$
y_{j}=\frac{\sum_{h=1}^{H} \mu_{h} w_{h j}}{\sum_{h=1}^{H} \mu_{h}}
$$

A set of input and output data learning data corresponding to each $\left(x_{i}^{p} \cdots \cdots x_{m}^{p}, y_{1}^{p} \cdots \cdots \cdot y_{n}^{p}\right), p=$ $1 \cdots \mathrm{L}$ and the output square error of the inference network are thus given by:

$$
E_{L}=\frac{1}{2} \sum_{j=1}^{n}\left(y_{j}-y_{j}^{L}\right)^{2}
$$

By applying the delta rule used in neural networks for inference network learning, the renewal amount during repeated computation for, the center of delete area of the distribution of the membership function, and $w_{h j}, m_{k i}$, the real number of the rule consequent, are given by the following equation using $k_{m}$ and $k_{w}$ as learning constants:

$$
\begin{aligned}
& m_{k i}-x_{k i} \geq 0 \\
& k_{m} \frac{\partial E_{L}}{\partial m_{k i}}=-k_{m} \sum_{j=1}^{n}\left(y_{j}-y_{j}^{L}\right) \frac{\left(w_{h j}-y_{j}\right)}{\sum_{h=1}^{H} \mu_{h}} . \\
& \frac{\mu_{h}}{A_{h i}\left(x_{i}\right)} \cdot \frac{-1}{a_{k i}}
\end{aligned}
$$

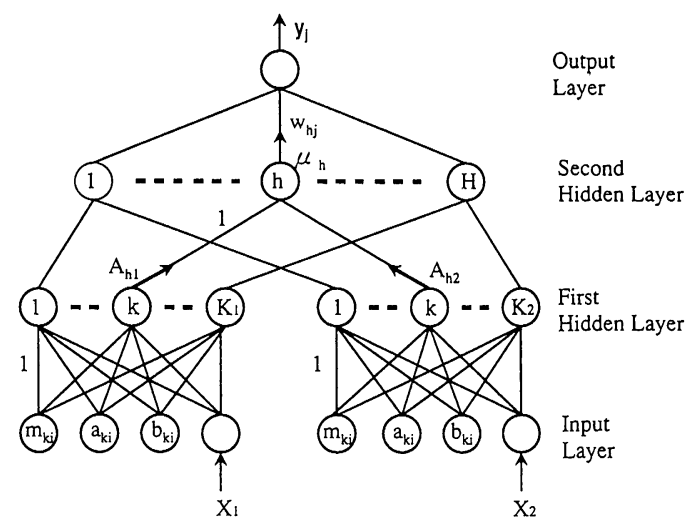

Fig. 4 Model of simplified inference method

$$
\begin{aligned}
& m_{k i}-x_{k i} \leq 0 \\
& k_{m} \frac{\partial E_{L}}{\partial m_{k i}}=-k_{m} \sum_{j=1}^{n}\left(y_{j}-y_{j}^{L}\right) \frac{\left(w_{h j}-y_{j}\right)}{\sum_{h=1}^{H} \mu_{h}} . \\
& \frac{\mu_{h}}{A_{h i}\left(x_{i}\right)} \cdot \frac{1}{b_{k i}} \\
& k_{w} \frac{\partial E_{L}}{\partial w_{h i}}=-k_{w}\left(y_{j}-y_{j}^{L}\right) \frac{\mu_{h}}{\sum_{h=1}^{H} \mu_{h}}
\end{aligned}
$$

In this case, the learning constants $k_{m}$ and $k_{w}$ are set respectively at $10^{-3}$ and 0.5 . The proposal by Masuda et al. (1993) which selects the rule with the highest level of contribution was adopted as the criterion for determining initial inference rules at the beginning of learning and additional inference rules.

\section{Estimating Run-down Distance of Slope Failure Debris with Fuzzy Inference Method}

Figure 5 shows the results of estimating the run-down distance obtained from the simplified fuzzy inference method using the membership functions shown Table 1, in Figs. 2.1 to 2.5. Overall, the fuzzy inference method produced shorter distance estimates for distances exceeding $60 \mathrm{~m}$ than actual run-down distance measurements. This overall tendency of the fuzzy inference method is even stronger in Fig. 6 which shows the results when analyzed under the same conditions using the quantification theory I. Particularly for run-down distance exceeding $40 \mathrm{~m}$, only two locations out of the estimated values based on the quantification theory I exceeded $40 \mathrm{~m}$, giving an 
Table 1 Elements used for fuzzy inference, partial correlation from the multidimensional quantification theory, and the segment conditions for membership functions

\begin{tabular}{|c|c|c|c|c|}
\hline \multicolumn{2}{|r|}{ Item } & \multirow{2}{*}{\begin{tabular}{|c|}
$\begin{array}{c}\text { Section } \\
\text { number }\end{array}$ \\
4
\end{tabular}} & \multirow{2}{*}{\begin{tabular}{|c|}
$\begin{array}{c}\text { Partial } \\
\text { correlation }\end{array}$ \\
0.440 \\
\end{tabular}} & \multirow{2}{*}{\begin{tabular}{|l}
$\begin{array}{c}\text { Segmenting conditions of the } \\
\text { membership functions before analysis }\end{array}$ \\
- $<9.54 \mathrm{~m}$ \\
- 9.54 to $18.32 \mathrm{~m}$ \\
- 18.32 to $43.43 \mathrm{~m}$ \\
- $>43.43 \mathrm{~m}$
\end{tabular}} \\
\hline Scale & Height of collapse & & & \\
\hline & Soil mass of collapse & 5 & 0.293 & $\begin{array}{l}-<29.7 \mathrm{~m}^{3} \\
-29.7 \text { to } 141.7 \mathrm{~m}^{3} \\
-141.7 \text { to } 222.8 \mathrm{~m}^{3} \\
\text { - } 222.8 \text { to } 1529.8 \mathrm{~m}^{3} \\
->1529.8 \mathrm{~m}^{3}\end{array}$ \\
\hline \multicolumn{2}{|c|}{$\begin{array}{l}\text { Amount of continuous rainfall } \\
\text { immediately before collapse }\end{array}$} & 3 & 0.255 & $\begin{array}{l}\cdot<143.7 \mathrm{~mm} \\
-143.7 \text { to } 478.9 \mathrm{~mm} \\
-478.9 \mathrm{~mm}\end{array}$ \\
\hline \multicolumn{2}{|c|}{ Slope down area condition } & 4 & 0.264 & $\begin{array}{l}\text { - Ascending (straight type), descending } \\
\text { (straight type) } \\
\text { - Flat area, ascending (S shape type) } \\
\text { - Ascending (curving type), ladder form } \\
\text { - Ascending (crest type), }\end{array}$ \\
\hline \multicolumn{2}{|c|}{ Slope longitudinal section } & 3 & 0.220 & $\begin{array}{l}\text { - Ascending (crest type), straight form } \\
\text { - Descending (sag type), composite (S } \\
\text { shape type) } \\
\text { - Composite (inverted S shape type) }\end{array}$ \\
\hline
\end{tabular}

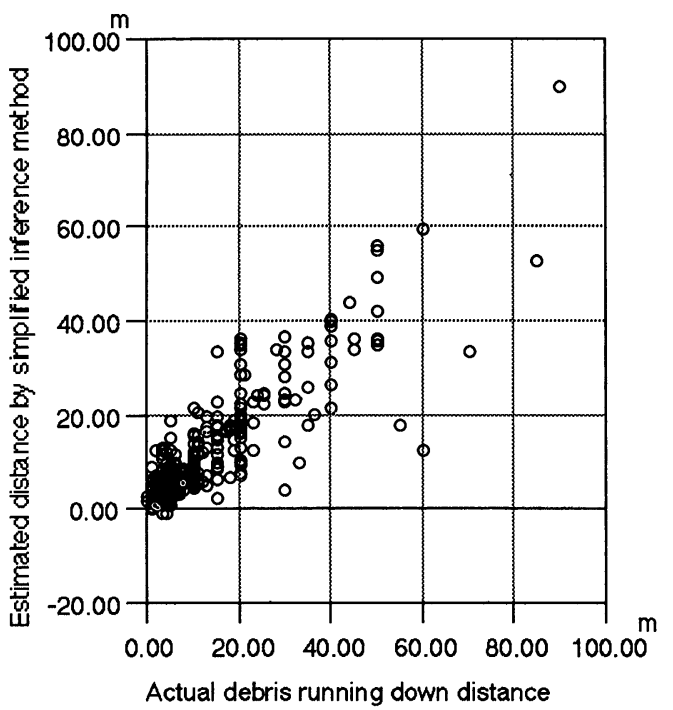

Fig. 5 Estimated debris running down distance by simplified inference method

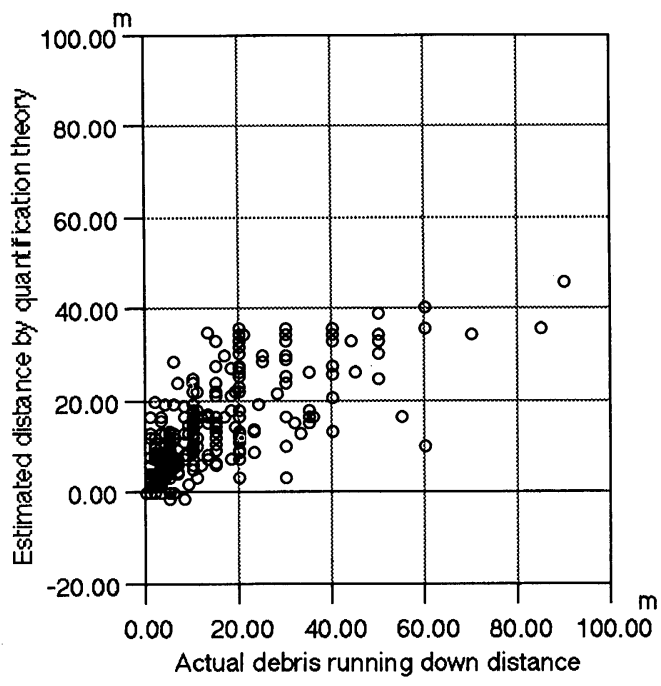

Fig. 6 Estimated debris running down distance by quantification theory 
error of more than $20 \mathrm{~m}$. Thus, although there were only 13 examples where the estimation error was more than $14 \mathrm{~m}$ and this was only $3.9 \%$ of the total, this error rate was $10.6 \%$ when using the multi-dimensional quantification theory. The difference can be explained by the fact that although the quantification theory I does not acknowledge fuzziness in the multi regression analysis of qualitative data, the fuzzy inference method does and actually learns according to the delta rule in order to describe the real phenomena a best as possible.

The dashed lines in Figs. 2.1 to 2.5 show the distribution of membership functions after tuning. Major changes in the height, down area condition, and longitudinal section of the slope can be seen. Nevertheless, the irregular result described by Masuda et al. (1993), which was produced by using an L-R type membership function has not been reproduced. According to the analysis, the characteristics of a scalene triangle are evident particularly in the down slope condition and the longitudinal section, proving the advantages of our proposed method. Consequently, our method reduces the ambiguity of the run-down distance when using qualitative data. Therefore, the ambiguity of qualitative elements can be analyzed by investigating the distribution of the membership function after each tuning, and this will inevitably lead to a more efficient re-segmenting of the proper elements.

\section{Conclusion}

Assuming that fuzziness exists in slope failure disaster data, we examined a method for estimating the run-down distance of slope failure debris based on a simplified fuzzy inference method. The following conclusions were drawn:

1) The membership function can be determined through fuzzy probability by using an L-R type membership function.

2) Calculation can be simplified compared to previous methods through formalization of a learning process in the simplified inference method using an L-R type membership function.

3) The proposed method proved more accurate than the quantification theory I and highly adaptable because of its learning functions when used to estimate the run-down distance of slope failure debris.

4) The ambiguity of the elements used in the analysis can be investigated by studying the distribution of the membership function after learning, which in turn will enable proper readjustment of element segmenting.

Since 720 inference alternatives can be produced from the number of membership function tunings in this analysis, a rapid delta rule algorithm needs to be developed in order to process the enormous amount of data and to reduce the calculation time required. It will also be necessary to develop inference systems that correspond with other run-down mechanisms such as those which exceed $50 \mathrm{~m}$ and thus display avalanche characteristics. These are some of the issues which must be addressed in the future.

\section{References:}

Ashida, K., Egashira, S. and Otuki, H., 1983: Dynamic Behavior of A soil Mass Produced by Slpoe Failure, Anual Report of Kyoto Univer. Disaster Prevention Institute, Vol. 26, B-2, pp. 316-327, (In Japanese)

Japan Society for Fuzzy Theory and Systems, 1992: Fuzzy and Fuzzy Set, Nikkan Kogyo Shimbun, Inc., p. 297, (In Japanese)

Masuda, T. and Yaku, S., 1993: An Acqusition Method of Fuzzy Reasoning Rules by Neural Network with Dynamic Function of Hidden Units, Jour, of Japan Society for Fuzzy Theory and Systems, Vol. 5, No. 2, pp. 348-357, (In Japanese)

Mitui, H. and Oura, J., 1987: Report of Slope Failure Disasters, Tech. Memorandum of P.W.R.I., No. 2548, p. 157, (In Japanese)

Nomura, H., Hayashi, I. and Wakami, N., 1992: A Selftuning Method of Fuzzy Reasoning by Delta Rule and its Application to A Moving Obstacle Avoidance, Jour. of Japan Society for Fuzzy Theory and Systems, Vol. 4, No. 2, pp. 379-388, (In Japanese)

Okubo, S., Yoshimatsu, H. and Tunaki, R., 1995: An Estimation of Reach Distance for Slope Failure Debris, Jour. of Japan Landslide Society, Vol. 32, No. 2, pp. 26-31, (In Japanese)

Tanaka, K., 1991: An introduction to Practical Theory, Russell, Inc., p. 206, (In Japanese)

Tamaki, F., Kanagawa, A. and Ohta, H., 1993: Identification of Membership Functions Based on Fuzzy Observation Data, Jour. of Japan Society for Fuzzy Theory and Systems, Vol. 5, No. 2, pp. 308-317, (In Japanese)

Yoshimatsu, H. and Mukai, A., 1995a: A Prediction Method of Groundwater Table Fluctuations in Landslide Area by Neural Networks, Jour. of Japan Landslide Society, Vol. 31, No. 4, pp. 9-15, (In Japanese)

Yoshimatsu, H. and Nakamura, S., 1995b: Estimation of a Landslide Slip Surface Location by A Fuzzy Inference Method, Jour. of Japan Landslide Society, Vol. 32, No. 1, pp. 1-7

（原稿受理日 平成 6 年 9 月 6 日） 
可能性線形回帰分析による地雿時の切土のり面・斜面の崩壊危険度判定の検討

「地すへり」Vol. 32, No. 3 (通巻第 123 号) pp. 1 9, 1995 年（平成 7 年）12月

寺田秀樹, 船山 淳, 大浦二朗, 須原 茂

可能性線形回帰分析により, 地震時の斜面崩壊の危険度評価を試みた。その結果, 表層崩壊において地震加速 度に影響される要因は主に地形要因であるとするモデルが同定された。他の地震による崩壊地を適用したところ, 適用の幅が小さいという問題点が指摘された。

An Estimation Method of Running Down Distance of Slope Failure Debris by a Fuzzy Inference Method Based on L-R Type Membership Function 「地すへり」Vol. 32, No. 3 (通巻第 123 号) pp. 10 16, 1995 年（平成 7 年）12 月

Hiroyuki Yoshimatsu and Saburo NAKAMURA

がけ崩れの崩土の到達距離に関する災害データは, 災害直後に収集されることもあってファジィネスを有して いる。これら災害データについて到達距離に関与する要因を L-R 型メンバーシップ関数で表わし，デル夕則によ る学習結果のファジィ推論より崩土の到達距離を予測する手法を提案した。この手法は学習機能を有することよ り汎化性の高い手法であるとともに解析に使用する要因の曖昧性が検討できることを明らかにした。

\section{くさび杭設計のための試論}

「地すべり」Vol. 32, No. 3 (通巻第 123 号) pp. 17 23, 1995 年（平成 7 年）12月 小島義孝, 山田言政, 渡邉直人, 速水博秀

くさび杭の新しい理論による設計法を検討した。この設計法では杭に作用する横荷重と移動層および不動層に 発生する地盤反力の釣り合い,さらに移動層スライスに於けるカとモーメントの釣り合いを考慮した理論にもと づき設計式を導いた。このため杭のたわみ方程式として, 移動層に発生する地すべり変位を考慮した式を用いた。 また斜面の安定評価理論によって杭に作用する横荷重を算定した。なお杭に作用する横荷重は従来の設計法と同 様, 移動層, 不動層の境界に作用する集中力を仮定した。また杭設置後の斜面の全体安全率の判定法についても 検討を行った。

\section{第三紀層地すべりの移動解析}

「地すべりVol. 32, No. 3 (通巻第 123 号) pp. 24〜31，1995 年（平成 7 年）12月 丸山清輝

本文では，第三紀層地すべりにおける地すべり動態観測結果をもとに，間隙水圧及び地下水位と地すべり日移 動量との時系列的な関係について検討した。その結果, 間隙水圧及び地下水位の変化による地すべり日移動量の 時系列変化は，粘土のクリープ特性をもとにした式により求められることが分かった。

新潟県松之山地すへり地域の地下水の水質について

「地すへり」Vol. 32, No. 3 (通巻第 123 号) pp. 32〜40, 1995 年（平成 7 年） 12 月

渡部直喜, 㖪津史也, 大木靖街, 佐藤 修

新潟県松之山地すべり地域の地下水の水質を調査・分類・整理し, 水一岩石相互作用の見地から地下水の形成過 程を考察した。大部分の地下水の水質は, 母岩の特徵をよく反映しており, 地下に浸透した水と母岩との水一岩石 相互作用によって形成された。一方, 水と母岩との反応では形成できない $\mathrm{Na}-\mathrm{Cl}$ 型の地下水もみとめられる。 $\mathrm{Na}-\mathrm{Cl}$ 型の地下水は松之山温泉の泉質に類似し, 断層の近傍に分布する傾向にある。また, 高い $\mathrm{CO}_{2}$ 分圧の条件 下で形成された地下水や水温の高い地下水もみとめられる。松之山地域の地すべり地の一部の地下水には, 断裂 を通じて上昇してくる地下深部の熱水の寄与がある。 